\begin{tabular}{ll}
\hline \hline MINING AND METALLURGY INSTITUTE BOR & ISSN: 2334-8836 (Štampano izdanje) \\
UDK: 622 & ISSN: 2406-1395 (Online) \\
\hline \hline
\end{tabular}

\title{
MONITORING THE QUALITY OF WATER, AIR AND \\ SOIL OF THE ASH AND SLAG LANDFILL OF TPP GACKO CASSETTE III, PHASES 1 AND $2^{* * *}$
}

\begin{abstract}
Combustion of coal in the thermo power plants, as well as by-products, generates the significant amounts of ash and slag, which immediately entails understanding the possibilities and target finding the appropriate way and places of disposal of these waste products, or potential locations for their disposal. Proper construction and treatment the landfills in monitoring the quality of the primary factors of the environment, will minimize the harmful effect of deposited material on the environment. This work presents a monitoring of water, air and soil of ash and slag landfill of TPP during the construction phase and during operation Cassettes III, Phases 1 and 2.
\end{abstract}

Keywords: landfill, ash and slag, monitoring

\section{INTRODUCTION}

The formed landfills - dumps of ash, both in the world and in our country, in essence, represent the biggest problem with regards to minimize their potential adverse impact on the environment, water, air and soil, and in this regard it should be careful in application the quality and resulting environmental protection measures, because the ash and slag landfills, air flows can very far away chase the ash, thereby jeopardizing the basic environmental factors. The one of the stated measures is covering the surface with dry clay and soil, as well as the formation of water surface in order to prevent the dispersal of ash by wind, then the ratio of ash and water (40:60), the application of geotextile foils and biological remediation.

Landfills also require large areas, and during the formation of the landfill the specific and adequate measures have to be taken to protect soil, groundwater and surface water from entering, washing, heavy metals and radionuclides from ash.

In order to reduce the amount of deposite ash and slag on landfills, a consideration should be given to their possible application in other branches of industry. For example, about $40 \%$ ash can be used as an additive in cement or as a substituent in some natural materials used in cement production, while the remaining $60 \%$ is deposited on a landfill.

\footnotetext{
* Mining and Metallurgy Institute Bor

** This work is the result of the Project No. TR33021 "Investigation and Monitoring the Changes of Stress-strain State in the Rock Mass "In-situ" around the Underground Rooms with Development a Model with Special Reference on the Tunel of the Krivelj River and Jama Bor", funded by the Ministry of Science and Technological Development of the Republic of Serbia
} 


\section{CONSTRUCTION OF ASH AND SLAG LANDFILL}

Specifically, the material disposed on landfills, can be used as a source of waste (chemical) gypsum, which is obtained by desulfurization of combustion gases that contain sulfur, which means that in removal the sulfur compounds from flue gas from the thermo power plants the sulfo-gypsum is formed. This way of dealing with waste ash is widely used in Europe. As the most promising, the possible use of ash from landfill is in its massive use as a building material for the production of cement and mortar. [14]

On the basis of many literature data where physico-chemical tests were carried out, ash and slag with their chemical composition and in particular percentage participation can be used as substitutes, i.e. substitute to the materials that are base in making the road pavements.

Figure 1 presents a cross-section of ash and slag landfill with a clear insight into the presence of layers, namely: a clayey layer, thick plastic layer, drainage layer, special layer of clay, thick plastic layer, protective layer / drainage layer, thick final plastic layer, disposed ash, drainage channel, and at the end a grass layer. These layers play an important role in the construction of landfill, thereby reducing the risk of perforation and ash emissions into the environment, or any accidents, passage of rainwater and leachate through drainage layers, which could lead to contamination of groundwater. For this reason there is the constant monitoring of the quality of groundwater and surface water (near the landfill), by appropriate legislation and regulations, where the supporting components shall not exceed the MPL (maximum permissible limits), as defined in the Regulations of the subject area

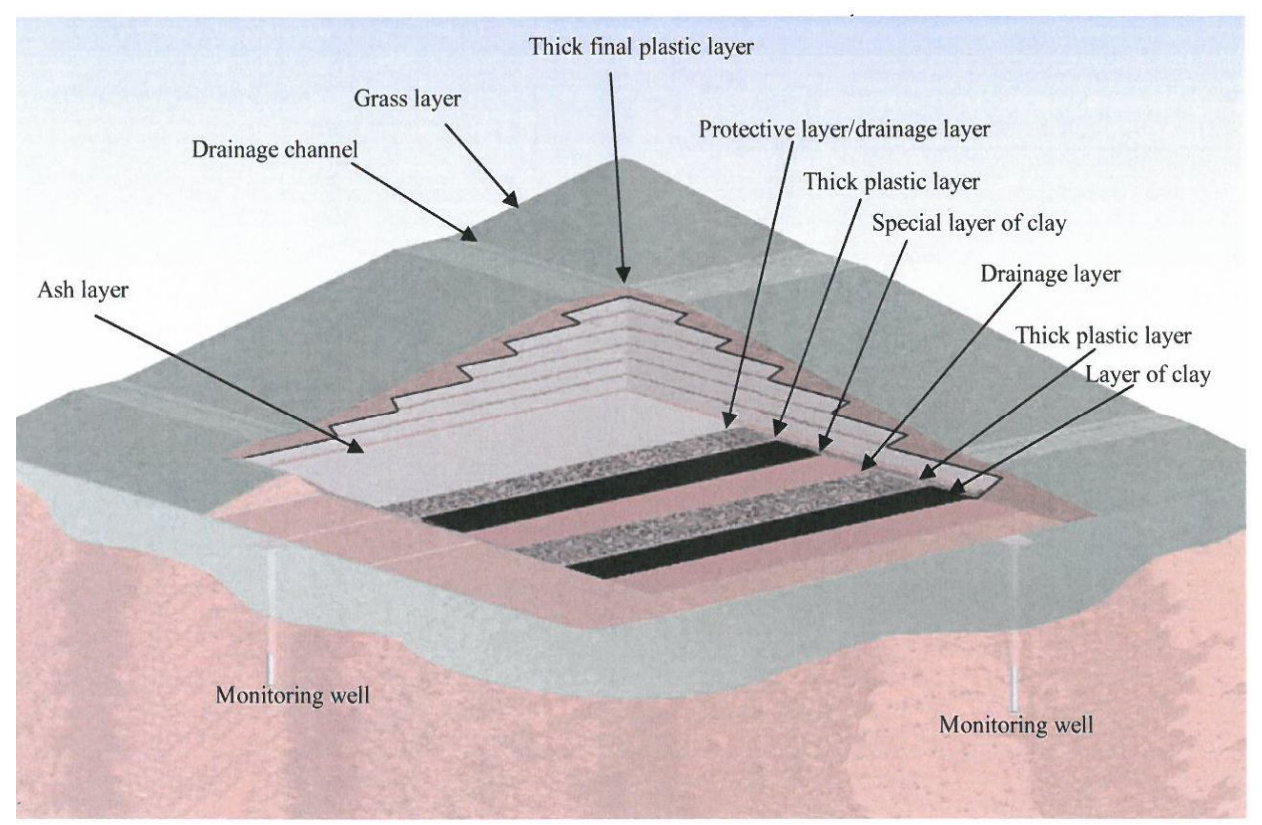

Figure 1 Cross section of ash and slag landfill 
After compacting of soil, a plastic coating/lining of several parts is placed. Then, a drainage layer is placed to collect leachate and a layer of clay to guarantee the complete safety of landfill. [15]

\section{AMOUNTS OF ASH AND SLAG}

From 2009 - 2011, about $53 \%$ of the products of coal combustion was reutilized in the industry, while the remaining part was disposed on landfills or shipped to the warehouses. According to the international data, in 2010, about 780 million tons of combustion products were produced. Guided by this figure as a valid data, it means that around 360 million tones of products from coal were deposited and such trend is expected in the future. [16]

Chemical composition of ash is in a function of the type of coal that is burned in TPP. Generally, more than $95 \%$ ash consists of silicon, aluminum, iron and calcium in the oxides form, then potassium, sodium, magnesium. It can also include a wide range of trace elements in varying concentrations. For example: antimony, arsenic, barium, cadmium, chromium, lead, mercury, selenium, strontium, zinc, and other metals. [13].

In 2007 , the US has produced 131 million tons of products from coal combustion. Approximately $43 \%$ was used in an appropriate manner, while about 75 million tons was disposed on the landfills. Using the fly ash in the construction industry instead of disposal, the costs of environmental degradation and energy are avoided, which is indicated by the following constitution. For each ton of fly ash that can be used as a substituent for portland cement, it is prevented to approximately tons of carbon dioxide to be released into the atmosphere. Also about 55 liters of oil is needed for the production of one ton of cement. As an advantage of using these waste materials, the following is stated: the application of ash in the cement industry as a replacement of portland cement requires less water, which tends to the preservation of this limited resource. The application of slag that is a substitute for sand, eliminates the potential risk of silicosis, which is dangerous to the human health. From the above mentioned, it can be seen the economic and environmental advantage of application the ash and slag from landfills instead of introducing the new materials. [17]

According to the American Coal Ash Association (ACAA), in 2006, the US generated approximately 18.6 million tons of ash and 2 million tons of slag. Of these, about $45 \%$ of disposed material was again found its use as shown in Figure $2 \mathrm{a}$ and Figure 2b. (Figure 2a, the use of fly ash as a substrate in the construction of roads; Figure $2 \mathrm{~b}$, about $40 \%$ of plasterboard production in the USA uses synthetic gypsum).
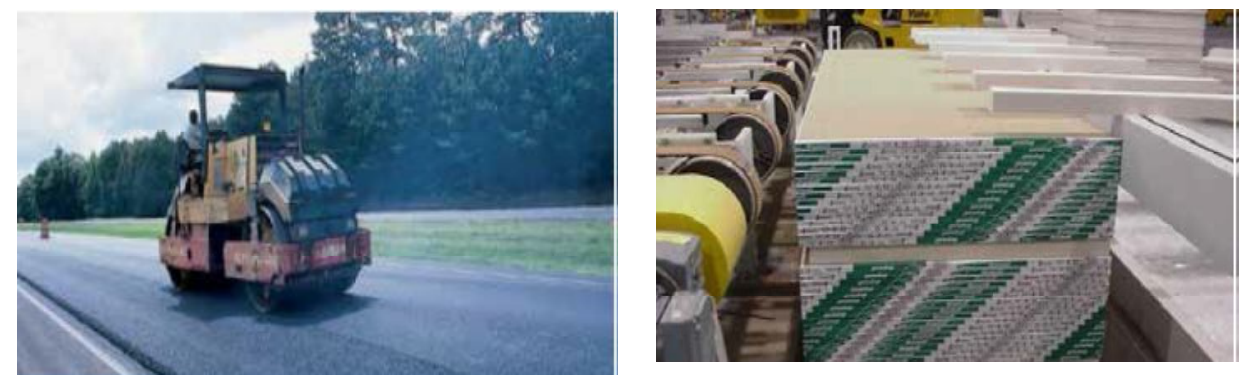

Figures 2 a) The use of slag as substrate in road construction, b) Gypsum plates made of synthetic gypsum, USA 


\section{DESCRIPTION AND LOCATION OF TPP GACKO}

The mine and TPP Gacko are located in the Gatački energy basin in the southeastern part of the Republic Srpska. Thermal power plant is a powerful and significant thermal power production capacity with an annual production and transfer into a common power system of effective 1.65 billion KWh of electricity. The design and technical solutions have envisaged total installed capacity of $600 \mathrm{MW}$ with phased implementation of $1 \times 300 \mathrm{MW}$ in the first phase and $1 \times 300$ MW in the next phase, and based on utilization the resources of Gacko lignite.

The product of coal combustion in TPP Gacko is ash and slag that require an adequate system of disposal on the proposed site. The resulting ash belongs to the calcium ash. In this ash, predominant share of $\mathrm{CaO}$ in contact with the water goes into $\mathrm{Ca}(\mathrm{OH})_{2}$.

According to the existing technological system, the ash in dry state from TPP Gacko, pneumatically is transported to two concrete silos where it is temporarily stored. Ash fluidization is done in the silos, and discharging and dosing of the required amount of ash is done with the help of sectoral dispensers. Dry ash from the sectoral dispenser, the amount of $150 \mathrm{t} / \mathrm{h}$, leaves by the closed pipeline to the closedconditioner with conical bottom of the unit, volume $32 \mathrm{~m}^{3}$.

Technological tests, conducted by the Investor, have concluded the optimal range for solid content in preparation the hydro mixture of ash and water of $40-42 \%$.

The landfill is located in the south of the TPP, which is formed within the open pit, i.e. the cassettes were formed for disposal of ash and slag. Currently, filling of the cassette III in phases 1 and 2 is carried out. During the exploitation process of the landfill, monitoring and auscultation of the ash and slag landfill are carried out in TPP gecko open pit Gračanica. The process of monitoring and auscultation are aligned with the European Directive on waste disposal on the landfill "COUNCIL DIRECTIVE 1999/31 / EC on the landfill of waste of April 26, 1999 ", as well as the Standard for design of earth dams and hydro-technical embankments - SRPS U. C5.020.

The ash and slag landfill of TPP Gacko is located on the western side of the town of Gacko at a distance of TPP Gacko by crow flies of about $1000 \mathrm{~m}$. On the west side is the river Gračanica, and on the southeast side is the relocated riverbed of the river Gračanica and on the southwest side is the southern final contour of the field "A" or riverbed of the river Musnica. On the north side, there are internal and external landfills of marl from the open pit Gračanica.

The process of coal mining at the open pit Gračanica has resulted into deterioration of the environment, i.e. there was a degradation of large land areas as well as disturbance the regimes of surface and groundwater. The construction of TPP Gacko has damaged even more the environmental quality. The ash and slag landfills had the major impact.

Fly ash is the finest fraction remaining after coal combustion in thermal plants [1]. Fly ash is a heterogeneous mixture of particles of different physical, chemical, mineralogical and morphological characteristics, which is produced by coal combustion in thermal power plants and characterized by a certain quality of burnt coal, combustion technology and combustion conditions [1]. Fine ash fractions can have a strong impact on degrading the environment, especially during strong winds, when being spread in the environment, which may lead to the major environmental problems, primarily impairs the health of population, bearing in mind that this material was categorized as hazardous waste [3]. 


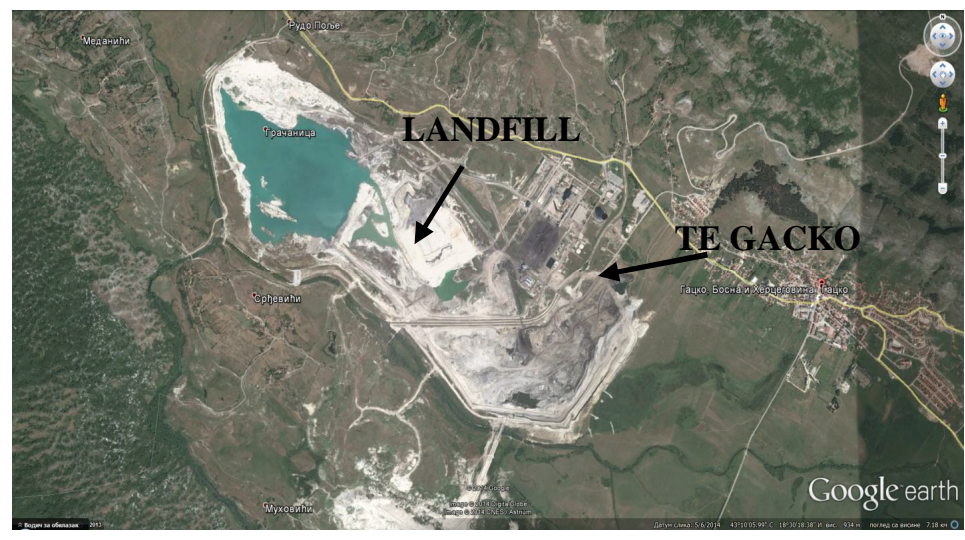

Figure 3 Satellite image of ash and slag landfill

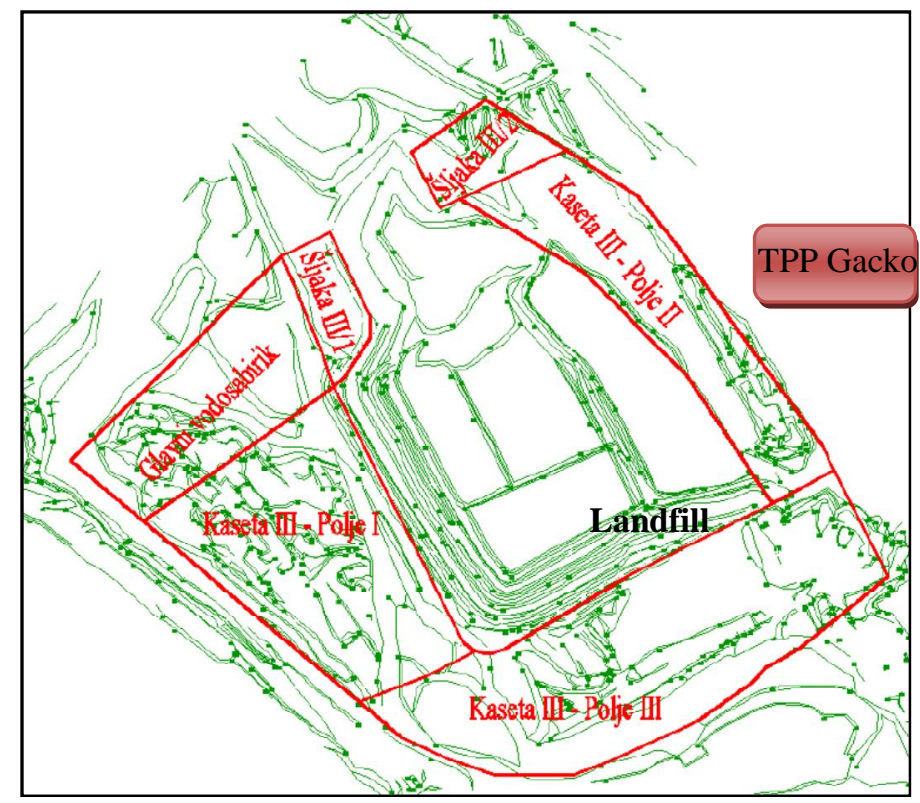

Figure 4 The space provided for Cassette III

However, the air pollution is eliminated because the waste raw material is transported to the landfill in the form of hydro mixture, i.e. in wetted or submerged state. The fly ash from TPP Gacko belongs to the type of carbonaceous ash (high content of $\mathrm{CaO}$ ), which means that it has cementation properties and in contact with water builds a compact material of certain mechanical strength.
In this way, the emission of fine ash particles in the air is prevented.

\section{CONSTRUCTION OF THE LANDFILL}

Construction of the landfill is carried out in two stages. The initial situation for the formation of landfill is the formed dump on the Cassettes I and II to the final elevation 
K+940 m, and the prepared surface of the phase 1 Cassette III. The initial landfill area of $141750 \mathrm{~m}^{2}$ was formed by construction the massive initial embankment of waterproof material on three sides and terrain slope to the Cassette I. The bottom of the landfill is coated with plastic foil for protection of soil and groundwater from leachate.
Underneath the plastic foil was placed drainage for evacuation of underground water, which are drained into the pumping station of leachate and drainage water. The initial situation in the phase 2 is practically the final appearance of the landfill at the end of phase 1. The final appearance of the ash and slag landfill in the phase 2 is given in Figure 5.

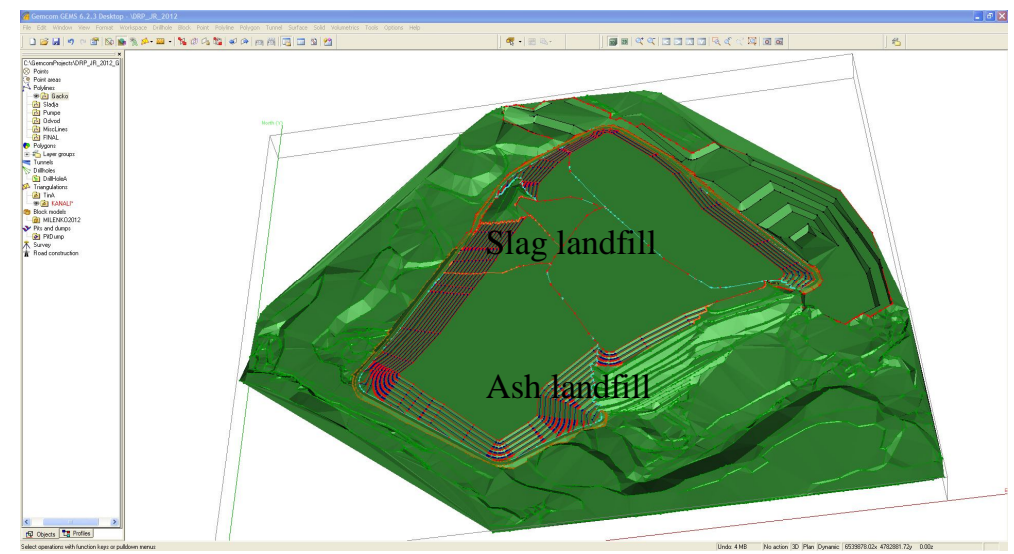

Figure 53 model of the ash and slag landfill in the phase 2 kasete III in the program Gemcom 6.2

\section{MONITORING}

Monitoring and auscultation of the ash and slag landfill of TPP Gacko the open pit Gracanica, Cassette II, phases 1 and 2 are aligned with the European Directive on waste disposal on the landfill "COUNCIL DIRECTIVE 1999/31/EC on the landfill of waste of April 26, 1999", as well as the Standard for design of earth dams and hydrotechnical embankments - SRPS U. C5.020.

The mentioned Directive has defined:

1. Monitoring during construction the landfill;

2. Monitoring during operation the ash and slag landfill;

3. Monitoring after closure the landfill.

\subsection{Monitoring during construction the landfill}

Monitoring of the landfill has included: quality of air, surface and groundwater, soil and noise.

\section{Air quality monitoring}

During implementation of works at the landfill, due to the presence of working machines (loaders, bulldozers ...), the emission from the internal combustion engines is expected. During operation of mining machinery, driven by internal combustion engines, emit harmful gases are emitted: nitrogen oxides $\left(\mathrm{NO}_{\mathrm{X}}\right)$, carbon-monoxide $(\mathrm{CO})$, carbon-dioxide $\left(\mathrm{CO}_{2}\right)$, sulfur-dioxide $\left(\mathrm{SO}_{2}\right)$, soot and dust particles; which are classified as poor sources of pollution of local importance. Endangering the basic factors of the environment, water, air and soil due to the emission of gases in the atmosphere will not be developed, having in mind that the works are current, i.e. transient character and limited only to the intended surface with minimum immediate impact on the immediate environment.

\section{Noise monitoring}

Within the monitoring of noise levels, on and around the subject complex, it is nece- 
ssary to perform the measurements of noise levels, whose intensity will be determined by the type of operation machines and their technical condition. A negative impact of noise on the environment is not expected, considering that the works are current and limited to the intended surface. The permitted noise levels are regulated by the Law on Protection against noise (Official Gazette of Federation B\&H, 110/12)

\section{Surface water monitoring}

Turbidity of the water may occur in the period of implementation of certain works on excavation, backfilling and disposal of materials. Water quality parameters to be included in the monitoring are: $(\mathrm{pH}$ value, temperature, ammonia nitrogen, nitrite nitrogen, nitrate nitrogen, phosphorus, sediment deposition after $0.5 \mathrm{~h}$, total suspended solids, BPK5 at $20^{\circ} \mathrm{C}$, HPK dichromatic, $\mathrm{PAH}, \mathrm{PCBs}$, phenolic index, mineral oils, detergents, iron, manganese, lead, cadmium, arsenic, total chromium, sulfates, chlorides, fluorides, ....), with the obligatory included turbidity and water temperature and water flow (on measuring profiles), according to the Regulation on water classification and categorization of watercourses (Official Gazette of RS, 42/01).

\section{Monitoring the groundwater quality}

Installing the new piezometers around Cassettes III, (6 pcs.), in addition to the existing ones on Cassettes I and II, the groundwater level will be monitored as well as their quality. Evaluating the groundwater quality is done using the parameters that are also monitored in surface water.

\section{Monitoring the soil quality}

It must be provided during the formation of the landfill, in order to possibly observation the negative impact of the works in forming the landfill on land. As the pollution of groundwater is followed by pollution of surrounding soil, the groundwater monitoring results can be analyzed as relevant for the assessment of soil conditions at the loca tion, and according to the Regulation on determining the harmful and hazardous substances in soil and methods of their analysis (Official Gazette of Federation B\&H, 11/99). The analyzed parameters relevant to the assessment of the soil around the landfill are: soil $\mathrm{pH}$ and heavy metals in the soil $(\mathrm{Pb}$, $\mathrm{Cu}, \mathrm{Zn}, \mathrm{As}, \mathrm{Cd}, \mathrm{Ni}, \mathrm{Cr}$ ).

\subsection{Monitoring during operation the ash and slag landfill}

According to the mentioned directive during operation and after closure of the landfill, monitoring should be done on:

- Meteorological parameters;

- Surface water;

- Leachate;

- Groundwater;

- The amounts of rainwater;

- Stability of landfill body.

\section{Monitoring the meteorological parameters}

The European Directive on waste disposal requires the monitoring of meteorological parameters during its exploitation. In the active phase of the landfill operation the following measurements are: amount of rainfall, temperature, rate and direction of air flow, evaporation and atmospheric humidity are monitored on a daily basis. The measurements are processed in the landfill laboratory or obtained from the nearest meteorological station, as long as required by the competent authority in accordance with law and regulation.

\section{Monitoring the surface water}

Monitoring of surface water is carried out during:

- Operation process of the landfill in order to compare with the "zero state" at the beginning of the landfill operation (first year) - every month, and then every three months. Sampling is performed by accredited laboratories.

- Permanent monitoring of surface water during operation of the landfill with shortened chemical and bacteriological 
analyses is carried out every 15 days in the landfill laboratories, based on the Directive on waste disposal on landfills (1999/33/EC). Content of analyzed elements in water as possible potential polluters of surface water is defined by the Regulation on water classification and categorization of waterways (Official Gazette of RS, 42/01). Parameters to be monitored are: $\mathrm{pH}$ value, temperature, sedimentary and suspended solids, organic parameters $\left(\mathrm{KMnO}_{4}\right.$, BPK5, HPK), nitrates, nitrites, ammonium ion, chlorides, sulfates, sulfides, cyanides, detergents, oils and fats, $\mathrm{Fe}$, $\mathrm{Cr}, \mathrm{Cu}, \mathrm{Ni}, \mathrm{Cd}, \mathrm{Zn}, \mathrm{Pb}$, etc., estimated by the authorized laboratory.

\section{Monitoring the leachate}

Measuring the quantity and composition i.e. qualitative and quantitative parameters of collected leachate, will be carried out at the place designated for it, once a month during the operation of the landfill, in accordance with the already mentioned Directive. Composition of leachate will be checked on parameters that are also applied to surface water, and which are consistent with the statutory regulations in the field of water, 4 times per year (quarterly).

\section{Monitoring the ground water}

Groundwater samples are taken from hydrogeological objects (piezometers, batteries of piezometers or monitoring wells) from at least three points, and such schedule to follow the movement of groundwater. This testing of groundwater samples is performed in order to determine the possible developments of accidents in the protective layers of the landfill, or determining the groundwater pollution. In addition to determining the composition of groundwater, permanent measurements the groundwater levels shall be carried out in the built piezometers around the landfill.

In the first six months of the landfill operation, the measurement and testing of groundwater are carried out every 15 days (shortened chemical and bacteriological analyses). Samples of groundwater, taken at time intervals, are analyzed as complete chemical and bacteriological analyses in accredited institutions for this type of testing, 4 times a year in accordance with the law of governing the water, or the Regulation on water classification and categorization of waterways (Official Gazette of RS, 42/01).

\section{Monitoring the amount of rainwater}

Measuring the amount of rainwater in the area of the landfill and its related facilities in the wider protection zone shall be performed in accordance with the law governing the water.

\section{Monitoring the stability of the landfill body}

Monitoring the stability of the landfill body is done through monitoring data on the landfill body and sensor tracking the sealing coating - foil.

\section{Monitoring the air quality in the vicinity of ash and slag landfill}

The ash and slag landfill, Cassette III, during regular operation, shall not present the secondary source of emission and imission of fine ash particles. This effect is reduced, it can be said completely eliminated, because the transport of technogenic raw material in wetted or submerged state that minimizes the negative impact of deposited slurry on air and soil in the vicinity. Regarding to this, the subject complex needs from time to time, in accordance with the Law on air protection (Official Gazette of RS, 124/11) and the Regulation on the values of air quality (Official Gazette of RS, 124/12), monitoring the air quality, Annex I, IV, of mentioned Regulation. Assessment the air quality under Article 8 of the Law on air protection, shall be required in respect of concentrations of sulfur dioxide, nitrogen dioxide and oxides of nitrogen, particulate matter (PM10, PM2.5), lead, benzene and carbon monoxide, hydrocarbons, groundlevel ozone, arsenic, cadmium, nickel and benzo pyrene and emission of suspended 
particulate matter (PM10, PM2.5), and may be for other pollutants, which are determined by the relevant international regulations. It is necessary to monitor: the wind parameters (speed and wind direction); the hydromelteorological parameters: temperature, humidity and atmospheric pressure.

A republican network of measuring stations was established to monitor the air quality at the level of Republic Srpska.

\section{Monitoring the waste (ash and slag)}

Monitoring of waste includes regular waste characterization by an authorized institution in accordance with the Law on Waste Management (Official Gazette of RS, 53/02) and the Law on Amendments to the Law on Waste Management (Official Gazette of RS, 65/08). The obligation of the project holder to report on completed monitoring of waste the Ministry of the Republic of Srpska.

\section{Monitoring the soil quality}

According to the Regulations on determining the allowable amounts of hazardous and harmful substances in the soil and methods of their analysis (Official Gazette of $\mathrm{B} \& \mathrm{H}, 72 / 09$ ), Article 10, the regular check of soil is obligatory at least every four years in the vicinity of major urban areas, industrial facilities and roads, then lands where various waste materials are disposed, ash landfills from thermo power plants and tailing dumps.

The above Regulations stipulate the limit values of parameters, Articles 5, 6 and 7, which are tested in determining the quality of groundwater, or their harmful impact on physical, chemical and biological properties of soil.

\section{Technical monitoring the ash and slag landfill}

During many years of landfill operation, monitoring the ash and slag landfill is performed by an expert-authorized person responsible for observing the basic parameters that affect the operation of landfill, defined by the plan and program of landfill operation. Insight into the monitored parameters is done by the competent and inspection bodies in the form of periodic reports. Keeping the recording on situation in the field is recorded through observation logs and continuously monitored on optimization influential landfill operation that can cause accidents, the adverse impact on the environment, the activity of various external and internal factors and failure to follow the same basic protection measures during the landfill operation.

\section{CONCLUSION}

Proper access during construction the ash and slag landfill reduces its adverse effect on the main factors of the environment, water, air and soil.

Monitoring the quality of water, air and soil or adequate indicators (elements), prescribed by the legal regulations and rules of subject areas is the result of clear insight into the landfill state, primarily in the state of groundwater and surface water in order to prevent their degradation, i.e. pollution with ash due to a possible breakthrough of leachate in landfill through the drainage system.

Accident situation and pollution of groundwater may occur due to failure of the drainage system, which can be seen at the time of the accident and prevent a possible large-scale by monitoring the state in the built-in piezometers around the landfill, according to the developed plan and program for monitoring the state, which constantly has insight into the level and quality of ground water and thus reducing the risk of groundwater pollution to minimum. The soil quality is monitored over the monitoring parameters of groundwater quality.

Air quality monitoring is carried out on the orders of the competent authority but by introduction the new technologies of disposal as already noted in the work with higher water content in relation to the ash content in the formed hydro mixture, there will be no scattering of ash, thus the impact of ash on the air is completely reduced. 


\section{REFERENCES}

[1] I. Jovanović, M. Bugarin, S. Magdalinović: Review of contemporary world studies on characteristics of fly ash as a secondary mineral resource: Part 1. Mining and Metallurgy Engineering Bor, 2/2013, pp. 147-156.

[2] M. Mikić, D. Kržanović, M. Ljubojev: Overview of zone monitoring of current collector of the Krivelj River below flotation tailing dump "Veliki Krivelj", Serbia. XV Balkan mineral procesing congress, Proceedings, 12$16^{\text {th }}$ June 2013, Sozopol, Bulgaria.

[3] Lj. Obradović, D. Urošević, G. Tomić: Physical characterization of fly ash and slag from Medosevac dump, Mining Engineering, 1/2010, pp. 63-68.

[4] Tehnički projekat rekultivacije deponije pepela i šljake, Jun 2013.

[5] M. Ljubojev, D. Ignjatović, L. Djurdjevac Ignjatović, V. Ljubojev, Preparations for Investigation the Tunnel Route and Field Surveying, Mining Engineering Journal, No. 1, 2011, pp. 135-166.

[6] S. Krstić, M. Ljubojev, M. Mikić, V. Ljubojev: Methods of geotechnical investigations for rehabilitation and remediation the flotation tailing dump Veliki Krivelj (Serbia), XIV Balkan mineral processing congress, proceedings, Jun, 2011, Tuzla, BIH, pp. 851-853.

[7] S. Krstić, M. Mikić, M. Ljubojev, O. Musić, V. Ljubojev: Conditions of drainage of flotaion tailing of Veliki Krivelj, $43^{\text {rd }}$ International october conference on mining and metallurgy, proceedings, Octobar 2011, Kladovo, Srbija, pp. 221-238

[8] M. Mikić, D. Kržanović, S. Krstić: Overview of the current situation of major facilities of the flotation tailing dump Veliki Krivelj near Bor with special review to the collector of the Krivelj River, $43^{\text {rd }}$ International october conference on mining and meta- llurgy, Proceedings, Octobar 2011, Kladovo, Srbija, pp. 303-306.

[9] D. Kržanović, M. Mikić, M. Ljubojev: Analysis the spatial position of mining facilities of the Veliki Krivelj mine to the proposed tunnel route for relocation the Krivelj River, Mining Engineering, 3/2011, pp. 95-100.

[10] D. Kržanović, M. Mikić, M. Ljubojev: Analysis of development effects of the Veliki Krivelj mine on construction the new facilities for deviation the Krivelj River, Mining Engineering, 4/2011, pp. 57-64.

[11] S. Krstić, R. Lekovski, M. Mikić: Environmental protection from dust from flotation tailings Veliki Krivelj, Air protection 2011, Proceedings, Zrenjanin Hotel Vojvodina 7.-9.11. 2011. pp. 200-206.

[12] M. Mikić, D. Kržanović, M. Ljubojev. Auscultation and zone monitoring of current collector of the Krivelj river below flotation tailing dump "Veliki Krivelj", Serbia. 12 ${ }^{\text {th }}$ Scientific Geoconference SGEM 2012, proceedings volume I, Geology Exploration and Mining. Proceedings, $17-23^{\text {th }}$ June, Albena Bulgaria, pp. 465-472.

[13] V. Čudić, D. Kisić, D. Stojiljković, A. Jovović: Ash from thermal power plants assecondary raw material. Institute of Public Health, Belgrade, Economic Society TENT, Obrenovac, University of Belgrade, Faculty of Mechanical Engineering, Belgrade, Serbia, Thermal power plant ash as secondary raw material. April 2007.

[14] List EPCG - Nikšić, january 2007, http://www.ekopv1.00freehost.com/ elektro.htm

[15] www.ctsafeashlandfill.com

[16] http://www.worldcoal.com/news/ power/articles/Management_of_coal_c ombustion_wastes9

[17] http://www.coalashfacts.org 


\begin{tabular}{ll}
\hline \hline INSTITUT ZA RUDARSTVO I METALURGIJU BOR & ISSN: 2334-8836 (Štampano izdanje) \\
UDK: 622 & ISSN: 2406-1395 (Online) \\
\hline \hline
\end{tabular}

\section{MONITORING KVALITETA VODE, VAZDUHA I ZEMLJIŠTA DEPONIJE PEPELA I ŠLJAKE TE GACKO KASETE 3, FAZE 1 I $2^{* * *}$}

Izvod

Sagorevanjem uglja u termoelektranama, kao nus-produkat nastaju značajne količine pepela $i$ šljake, što odmah povlači za sobom sagledavanje mogućnosti $i$ ciljano iznalaženje adekvatnog načina $i$ mesta odlaganja ovih otpadnih produkata, odnosno potencijalne lokacije za njihovo deponovanje. Pravilnom izgradnjom i tretiranjem odlagališta-deponije, u praćenja kvaliteta osnovnih činioca životne sredine, minimiziraće se štetan uticaj deponovanog materijala, na životnu sredinu. U radu je dat monitoring praćenja vode, vazduha i zemljišta deponije pepela i šljake TE Gacko u toku faze izgradnje i za vreme eksploatacije Kasete III, faze 1 i 2 .

Ključne reči: deponija, pepeo i šljaka, monitoring

\section{UVOD}

Formirana odlagališta deponije i pepela kako u svetu tako i kod nas, u suštini predstavljaju i najveći problem, posmatrano sa aspekta minimiziranja njihovog eventualnog štetnog uticaja, na životnu sredinu, vodu, vazduh i zemljište, te s tim u vezi treba pažljivo pristupiti primeni kvalitetnih i rezultujućih mera zaštite životne sredine, jer sa deponija pepela i šljake, vazdušna strujanja mogu vrlo daleko da razveju pepeo, ugrožavajući pri tome osnovne činioce životne sredine. Kao jedna od tih mera navodi se i prekrivanje suvih površina glinom i zemljom, kao i formiranje vodene povšine, kako bi se sprečilo raznošenje pepela vetrom, zatim odnos pepela i vode,
(40:60), primena geotekstilnih folija, biološka rekultivacija.

Deponije takođe zahtevaju i velike površine, a prilikom formiranja deponija moraju se preduzeti konkretne i adekvatne mere kako bi se zaštitilo zemljište, podzemne i površinske vode od unošenja, ispiranjem, teških metala i radionukleida iz pepela.

Kako bi se reducirala količina odloženog pepela i šljake na deponijama, treba razmotriti mogućnost njihove eventualne primene u drugim granama industrije. $\mathrm{Na}$ primer: oko $40 \%$ pepela se može koristiti kao dodatak u cementu odnosno kao supstituenat nekim prirodnim materijalima koji se koriste u proizvodnji cementa, dok se preostalih $60 \%$ odlaže na deponiju.

\footnotetext{
* Institut za rudarstvo i metalurgiju Bor

** Rad je proizašao iz projekta broj TR33021 „Istraživanje i praćenje promena naponsko deformacijskog stanja u stenskom masivu ,in-situ“ oko podzemnih prostorija sa izradom modela sa posebnim osvrtom na tunel Kriveljske reke i Jame Bor", koji je finansiran sredstvima Ministarstva za prosvetu, nauku i tehnološki razvoj Republike Srbije
} 


\section{IZGRADNJA DEPONIJE PEPELA I ŠLJAKE}

Konkretno, materijal odložen na deponijama, može da se iskoristi kao izvor otpadnog (hemijskog) gipsa, do kojeg se dolazi desulfurizacijom gasova sagorevanja koji sadrže sumpor, što znači da bi se pri uklanjanju sumpornih jedinjenja iz dimnih gasova termoelektrana stvarao sulfo-gips. Ovaj način postupanja sa otpadnim pepelom uveliko nalazi primenu u Evropi. Kao najperspektivnija, moguća upotreba pepela iz deponija jeste u njegovoj masovnoj upotrebi kao građevinskog materijala, za proizvodnju cementa, maltera. [14]

Po osnovu mnogobojnih literaturnih podataka gde su rađena fizičko-hemijska ispitivanja, pepeo i šljaka sa svojim hemijskim sastavom i u određenom procenualnom učešću mogu se koristiti kao supstituenti, tj zamena materijalima koji su osnova u izradi putnih podloga.

Na slici 1 dat je poprečni presek deponije pepela i šljake, sa kojeg se ima jasan uvid u prisutnost slojeva i to: glinoviti sloj, debeo plastični sloj, drenažni sloj, specijalni sloj gline, debeo plastični sloj, zaštitni sloj/drenažni sloj, debeo finalni plastični sloj, odloženi pepeo, kanal za drenažu, i na kraju travnati sloj. Ovi slojevi igraju važnu ulogu pri izgradnji deponije, čime se smajuje rizik od proboja i ispuštanja pepela u životnu sredinu, odnosno eventualnih akcidentnih situacija, prolaz atmosferskih i procednih voda kroz drenažne slojeve, što bi dovelo do zagađenja podzemnih voda. Iz tog razloga prisutan je stalan monitoring kvaliteta podzemnih i površinskih voda (u blizini deponije), prema odgovarajućim zakonskim propisima i regulativama, gde prateće komponente ne smeju preći MDK (maksimalno dozvoljene granice), definisane Pravilnicima iz predmetne oblasti.

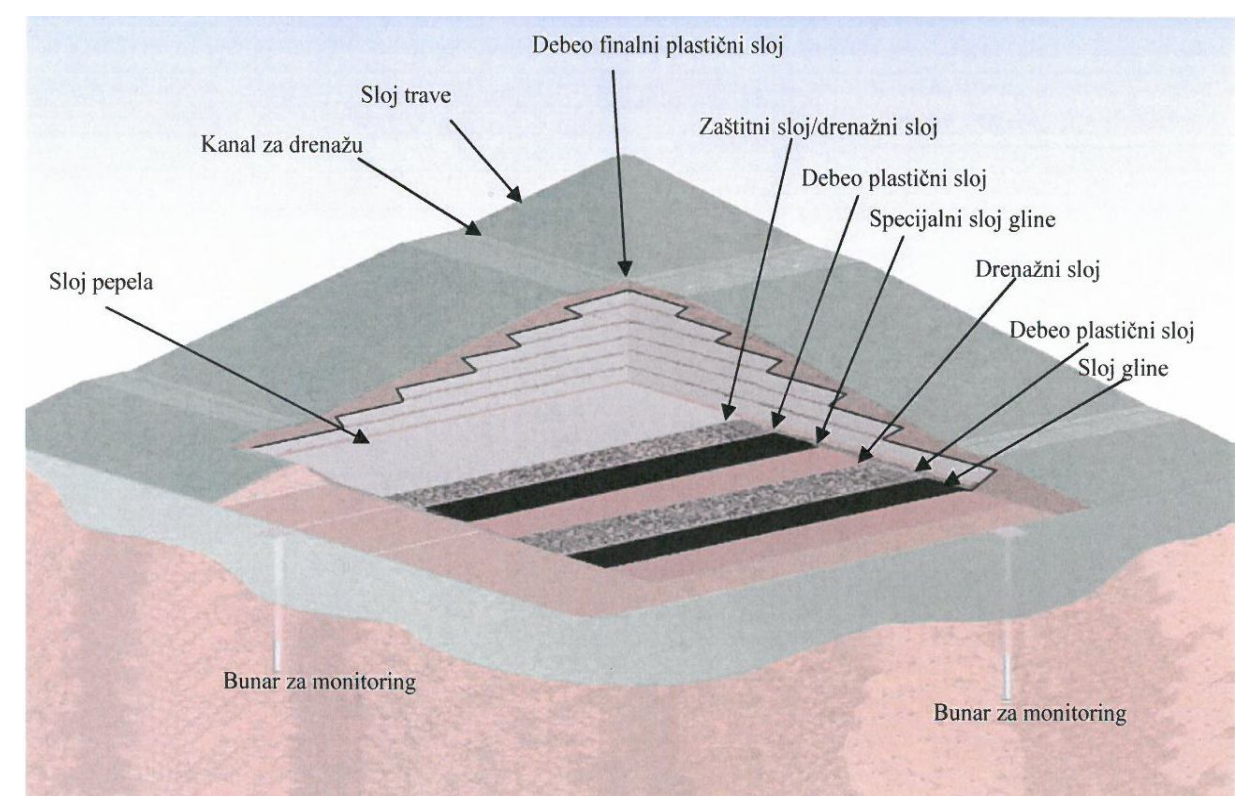

SI. 1. Poprečni presek deponije pepela i šljake 
Nakon kompaktiranja zemljišta postavlja se plastični sloj/obloga iz više delova. Zatim se postavlja drenažni sloj za prikupljanje procednih voda i sloj od gline čime se garantuje potpuna bezbednost deponije. [15]

\section{KOLIČINE PEPELA I ŠLJAKE}

Od 2009 - 2011, oko 53\% produkata sagorevanja uglja je ponovno iskorišćeno u industriji, dok je preostali deo odložen na deponije ili isporučen u skladišta. Prema svetskim podacima u 2010. godini proizvedeno je oko 780 miliona t produkata sagorevanja. Rukovodeći se ovom cifrom kao validnim podatkom, znači da je oko 360 miliona tona proizvoda sagorevanja uglja odloženo i da se očekuje i nadaje ovakav trend u narednom periodu. [16]

Hemijski sastav pepela je u funkciji vrste uglja koji se spaljuje u TE. Uopšteno, više od $95 \%$ pepela čine silicijum, aluminijum, gvožđe i kalcijum u oksidnoj formi, zatim kalijum, natrijum, magnezijum. Takođe može sadržati i širok spektar mikroelemenata $\mathrm{u}$ varijabilnim koncentracijama. $\mathrm{Na}$ primer: antimon, arsen, barijum, kadmijum, hrom, olovo, živa, selen, stroncijum, cink, i druge metale. [13]

U 2007 god, u SAD je proizvedeno 131 miliona tona proizvoda sagorevanja uglja. Oko $43 \%$ je iskorišćeno na adekvatan način, dok je oko 75 miliona tona odloženo na deponije. Korišćenjem letećeg pepela $\mathrm{u}$ građevinskoj industriji umesto što se odlaže na deponije izbegavaju se troškovi ekološke degradacije i energije, na šta ukazuje sledeća konstatcija. Za svaku tonu letećeg pepela koja se može koristiti kao supstituent za portland cement, sprečava se da se približno tona ugljen-dioksida ispusti $\mathrm{u}$ atmosferu. Takođe oko 55 litara nafte je potrebno za proizvodnju jedne tone cementa. Kao prednost korišćenja ovih otpadnih materijala navodi se i sledeće: primena pepela u cementnoj industriji kao zamena portland cementu zahteva manju količinu vode, čime se teži ka očuvanju ovog ograničenog resursa. Korišćenjem šljake koja je zamena za pesak, eliminiše se potencijalni rizik od silikoze, koja je opasna po zdravlje ljudi. Iz gore navedenog se može sagledati ekonomska i ekološka prednost primene pepela i šljake sa deponija umesto uvođenja novih materijala. [17]

Prema američkom Coal Ash Association (ACAA), tokom 2006. godine, u SAD generisano je oko 18,6 miliona tona pepela i 2 miliona tona šljake. Od toga oko $45 \%$ odloženog materijala ponovo je našlu svoju upotrebu kako je prikazano na slici $2 \mathrm{a}$ i slika 2b. (Slika 2a, upotreba pepela kao podloge pri izradi puteva; slika 2b, oko $40 \%$ gipsanih ploča prizvedenih u USA koristi sintetički gips).
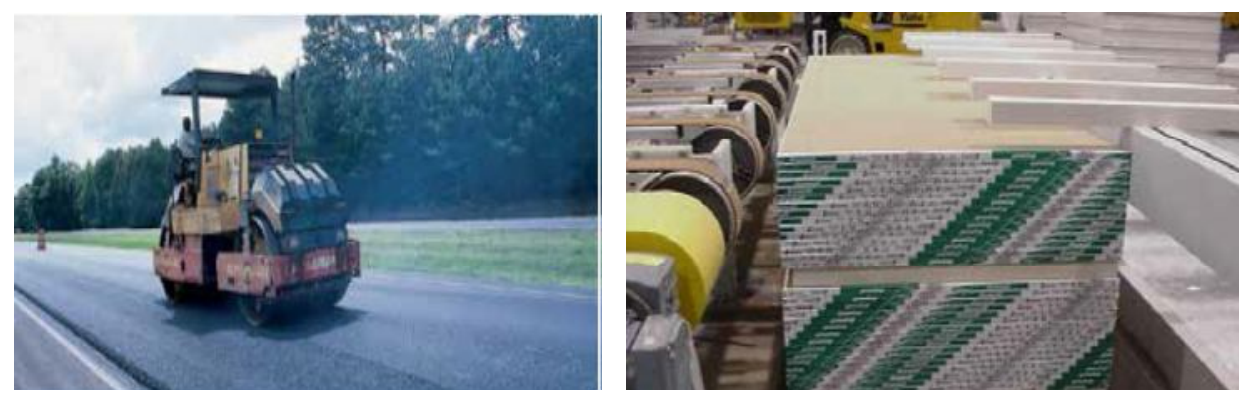

Sl. 2. a) upotreba pepela kao podloga pri izradi puteva i b) gipsane ploče proizvedene od sintetičkog gipsa, USA 


\section{OPIS I LOKACIJA TE GACKO}

Rudnik i Termoelektrana Gacko se nalaze u Gatačkom energetskom bazenu u jugoistočnom delu Republike Srpske. Termoelektrana je moćan i značajan termoenergetski proizvodni kapacitet sa godišnjom proizvodnjom $\mathrm{i}$ predajom $\mathrm{u}$ zajednički elektroenergetski sistem efektivnih 1.650.000.000 KWh električne energije. U koncepciji i tehničkim rešenjima predviđena je ukupna instalisana snaga od $600 \mathrm{MW}$ sa faznom realizacijom 1x300 MW u prvoj fazi i 1x300 MW u narednoj fazi, a na bazi iskorišćenja resursa gatačkog lignita.

Produkat sagorevanja uglja u TE Gacko, predstavlja pepeo i šljaka za koje je neophodno da se adekvatnim sistemom deponuju na predviđenu lokaciju. Nastali pepeo pripada grupi kalcijskih pepela. U ovom pepelu preovlađuje učešće $\mathrm{CaO}$ koji u kontaktu sa vodom prelazi u $\mathrm{Ca}(\mathrm{OH})_{2}$.

Po postojećem tehnološkom sistemu pepeo se u suvom stanju, iz TE Gacko, pneumatski transportuje do dva betonska silosa gde se privremeno skladišti. U silosima je izvršena fluidizacija pepela, a pražnjenje i doziranje potrebne količine pepela vrši se uz pomoć sektorskih dozatora. Suvi pepeo iz sektorskog dozatora u kolicini od $150 \mathrm{t} / \mathrm{h}$, odlazi zatvorenim cevovodom do zatvorenog kondicionera sa konusnim dnom jedinične zapremine od $32 \mathrm{~m}^{3}$.

Sprovedenim tehnološkim ispitivanjima od strane Investitora, izvodi se zaključak optimalnog opsega za sadržaj čvrstog u pripremi hidromešavine pepela i vode od $40-42 \%$.

Južno od TE Gacko nalazi se deponija, koja je formirana unutar površinskog kopa tj. formirane su kasete za deponovanje pepela i šljake. Trenutno se vrši zapunjavanje kasete III u fazi 1 i 2 . U toku procesa ekspoloatacije deponije vrši se monitoring i oskultacija deponije pepela i šljake TE Gacko PK Gračanica. Proces i monitoringa oskultacije su usklađeni sa Evropskom direktivom o odlaganju otpada na deponije "COUNCIL DIRECTIVE 1999/31/EC on the landfill of waste, of 26 april 1999", kao i Standardom za projektovanje nasutih brana i hidrotehničkih nasipa - SRPS U.C5.020.

Deponija pepela i šljake TE Gacko se nalazi na zapadnoj strani od grada Gacko i na udaljenosti od TE Gacko vazdušnom linijom oko $1000 \mathrm{~m}$. Sa zapadne strane je reka Gračanica a sa jugoistočne strane je izmešteno korito reke Gračanice, a sa jugozapadne strane je južna završna kontura polja „,A“ odnosno korito reke Mušnice. Sa severne strane se nalaze unutrašnja i spoljašnja odlagališta laporca površinskog kopa Gračanica.

Procesom eksploatacije uglja na površinskom kopu Gračanica došlo je do narušavanja životne sredine tj. došlo je do degradiranja velikih povšina zemljišta kao i poremećaja režima površinskih i podzemnih voda. Izgradnjom termoelektrane TE Gacko kvalitet životne sredine se još više narušavao. Veliki uticaj na to su imale deponije pepela i šljake.

Leteći pepeo predstavlja najfiniju frakciju koja zaostaje nakon sagorevanja uglja u termalnim postrojenjima [1]. Leteći pepeo je heterogena mešavina čestica različitih fizičkih, hemijskih, mineroloških i morfoloških osobina, koja nastaje sagorevanjem uglja u termoelektranama i čije su karakteristike određene kvalitetom izgorelog uglja, tehnologijom sagorevanja i uslovima sagorevanja [1]. Fine frakcije pepela mogu imati jak degradirajući uticaj na životnu sredinu i okolinu, posebno u periodu jakih vetrova, kada se raznose po okolini, što može dovesti do velikih ekoloških problema, a pre svega narušavanja zdravlja stanovništva, imajući u vidu da je ova sirovina kategorisana kao opasan otpad [3]. 


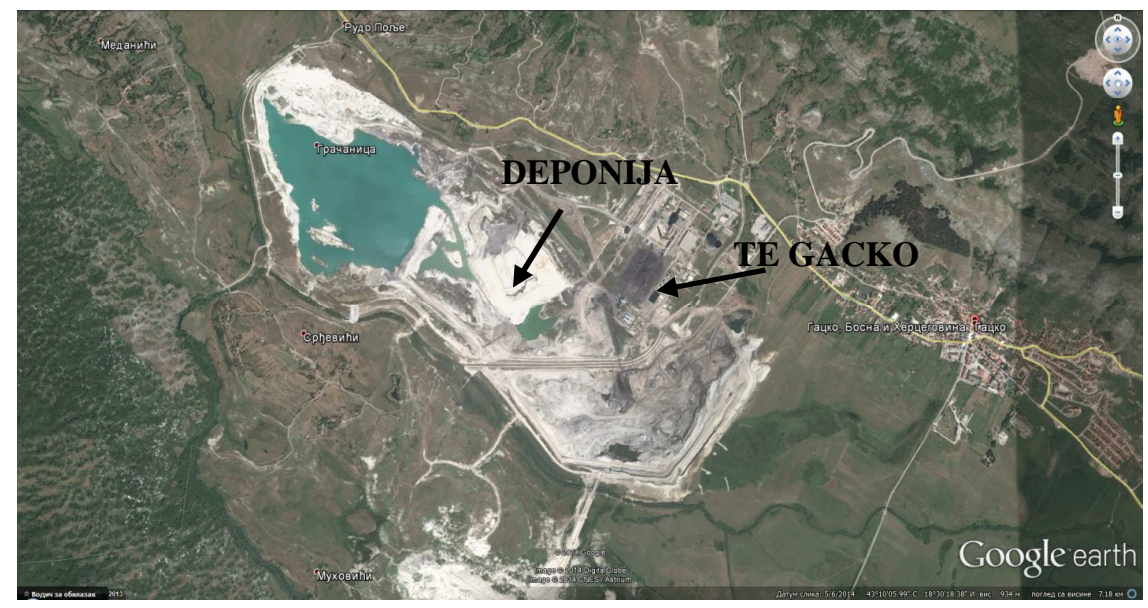

Sl. 3. Satelitski snimak lokacije deponije pepela i šljake

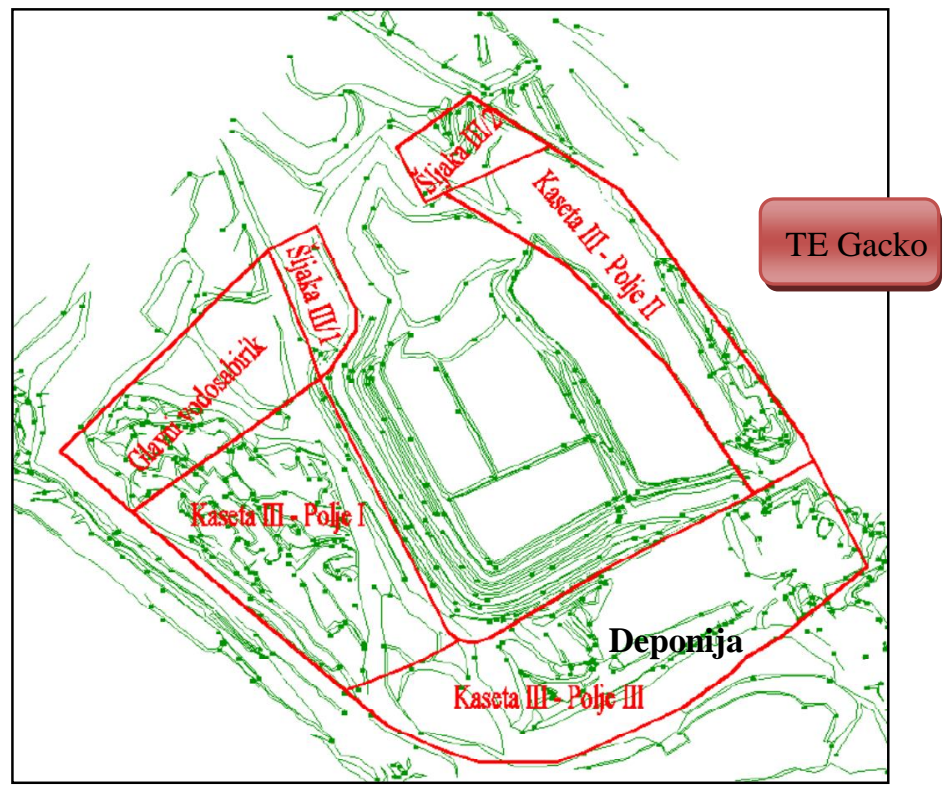

SI. 4. Prostor predviđen za kasetu III

Međutim, aerozagađenje je eliminisano, jer se tehnogena sirovina transportuje na deponiju u vidu hidromešavine tj. u okvašenom, odnosno potopljenom stanju. Naime, elektrofilterski pepeo iz TE Gacko pripada tipu karbonatnih pepela (visok sadržaj $\mathrm{CaO}$ ), što znači da poseduje cementaciona svojstva i u kontaktu sa vodom gradi kompaktan materijal određene mehaničke čvrstoće.
$\mathrm{Na}$ taj način sprečena je emisija finih čestica pepela u vazduh.

\section{IZRADA DEPONIJE}

Izrada deponije se odvija u dve faze. Početna situacija za formiranje deponije je formirana deponija na kasetama I i II do završne kote $\mathrm{K}+940 \mathrm{~m}$, i pripremljena 
podloga faze 1 kasete III. Početna površina deponije od $141.750 \mathrm{~m}^{2}$ forrnirana je izgradnjom masivnog inicijalnog nasipa od vodonepropusnog materijala sa tri strane i kosinom terena ka kaseti I. Dno deponije, je presvučeno plastičnom folijom za zaštitu zemljišta i podzemnih voda, od procednih voda. lspod plastične folije je postavljena drenaža za evakuaciju podzemnih voda, koje se odvode u pumpnu stanicu procedne $\mathrm{i}$ drenažne vode. Početna situacija u fazi 2 je praktično završni izgled deponije na kraju faze 1. Konačan izgled deponije pepela i šljake u fazi 2 je dat na slici 5 .

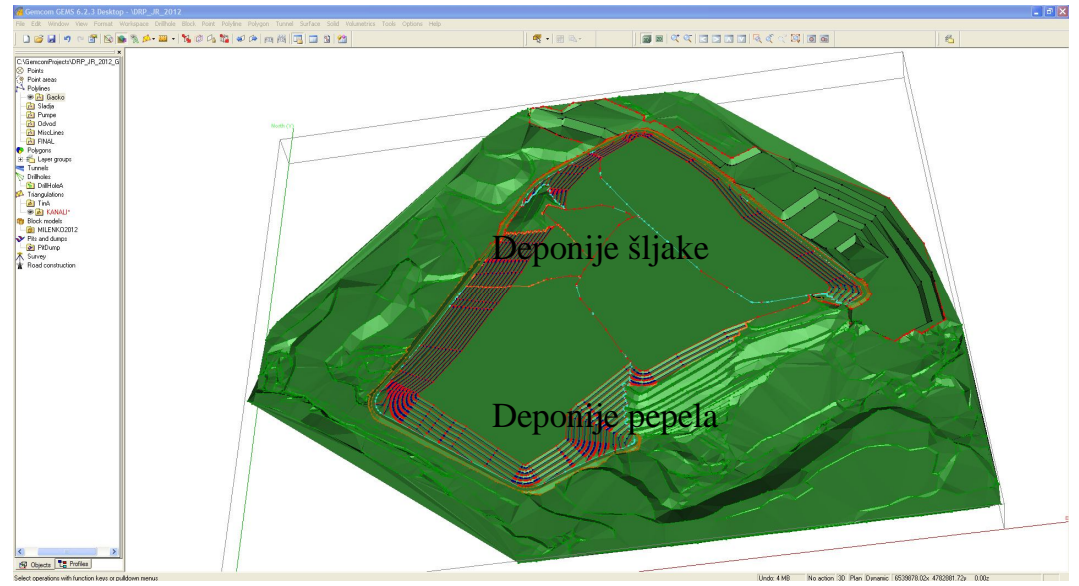

Sl. 5. 3D model deponije pepela $i$ šljake u fazi 2 kasete III u programu Gemcom 6.2

\section{MONITORING}

Monitoring i oskultacija deponije pepela i šljake TE Gacko PK Gračanica, Kaseta III, faza 1 i 2 usklađeni su sa Evropskom direktivom o odlaganju otpada na deponije "COUNCIL DIRECTIVE 1999/31/EC on the landfill of waste, of 26 april 1999", kao i Standardom za projektovanje nasutih brana i hidrotehničkih nasipa-SRPS U.C5.020.

Navedenom Direktivom definisan je:

1. Monitoring u toku izgradnje deponije;

2. Monitoring $\mathrm{u}$ toku eksploatacije deponije pepela i šljake;

3. Monitoring nakon zatvaranja deponije.

\subsection{Monitoring u toku izgradnje deponije}

Monitoringom deponije su obuhvaćeni: kvalitet vazduha, površinskih i podzemnih voda, zemljišta i buka.

\section{Monitoring kvaliteta vazduha}

$\mathrm{U}$ toku izvođenja radova na deponiji, usled prisustva radnih mašina (utovarivača, buldozera...), očekuje se emisija izduvnih gasova iz motora sa unutrašnjim sagorevanjem. Pri radu rudničke mehanizacije koju pokreću motori sa unutrašnjim sagorevanjem, emituju se štetni gasovi: azotni oksidi $\left(\mathrm{NO}_{\mathrm{X}}\right)$, ugljen-monoksid (CO), ugljen-dioksid $\left(\mathrm{CO}_{2}\right)$, sumpor-dioksid $\left(\mathrm{SO}_{2}\right)$, čestice čađi i prašine; koji se svrstavaju u slabe izvore zagađenja lokalnog značaja. Do ugrožavanja osnovnih činilaca životne sredine, vode, vazduha i zemljišta usled emisije gasova u atmosferu neće doći, imajući u vidu da su radovi trenutni, t.j. prolaznog karaktera i ograničeni su samo na predviđenu površinu, sa minimalnim trenutnim uticajem na neposrednu okolinu.

\section{Monitoring buke}

U sklopu monitoringa nivoa buke, na i oko predmetnog kompleksa, potrebno je 
vršiti merenja nivoa buke, čiji će intezitet biti uslovljen vrstom radnih mašina i njihovog tehničkog stanja. Ne očekuje se negativan uticaj buke na životnu sredinu i okolinu, obzirom da su radovi trenutni i ograničeni su na predviđenu površinu. Dozvoljeni nivoi buke regulisani su Zakonom o zaštiti od buke (Sl. Novine B i H 110/12).

\section{Monitoring kvaliteta površinskih voda}

Zamućenost vode se može pojaviti u periodu izvođenja određenih radova na iskopu, nasipanju i odlaganju materijala. Parametri kvaliteta vode koje je potrebno uključiti u praćenje su: ( $\mathrm{pH}$ vrednost, temperatura, amonijačni azot, nitritni azot, nitratni azot, fosfor, talog nakon $0,5 \mathrm{~h}$ taloženja, ukupne suspendovane materije, BPK5 pri $20^{\circ} \mathrm{C}$, HPK dihromatni, PAH, PCBs, fenolni indeks, mineralna ulja, deterdženti, gvožne, mangan, olovo, kadmijum, arsen, ukupno hrom, sulfati, hloridi, fluoridi, ...), uz obavezno uključenu mutnoću i temperaturu vode i protok vode (na mernim profilima), a Prema Uredbi o klasifikaciji voda i kategorizaciji vodotokova (Sl. gl. RS 42/01).

\section{Monitoring kvaliteta podzemnih voda}

Ugradnjom novih pijezometara oko Kasete III, (6 kom.), pored postojećih na kaseti I i II pratiće se nivo podzemnih voda kao i njihov kvalitet. Vrednovanje kvaliteta podzemnih voda vrši se pomoću parametara koji se prate i kod površinskih voda.

\section{Monitoring kvaliteta zemljišta}

Mora biti obezbeđen u toku formiranja deponije, kako bi se eventualno mogao uočiti negativan uticaj izvođenja radova formiranja deponije na zemljište. Kako zagađenje podzemne vode prati i zagađenje okolnog zemljišta, rezultati kontrole podzemnih voda se mogu analizirati kao relevantni za ocenu stanja zemljišta na predmetnoj lokaciji, a prema Uredbi o utvrđivanju štetnih i opasnih tvari u zemljištu i metodama njihovog ispitivanja (Sl. Novine federacije $\mathrm{BiH}$ br. 11/99). Ispitivani parametri relevanti za ocenu stanja zemljišta oko deponije su: $\mathrm{pH}$ zemljišta i teški metali u zemljištu $(\mathrm{Pb}, \mathrm{Cu}$, $\mathrm{Zn}, \mathrm{As}, \mathrm{Cd}, \mathrm{Ni}, \mathrm{Cr}$ ).

\subsection{Monitoring u toku eksploatacije deponije pepela i šljake}

Prema navedenoj direktivi za vreme rada i nakon zatvaranja deponije potrebno je vršiti monitoring:

- Meteoroloških parametara;

- Površinskih voda;

- Procednih voda;

- Podzemnih voda;

- Količine padavinskih voda;

- Stabilnosti tela deponije.

\section{Monitoring meteoroloških parametara}

Evropskom direktivom o odlaganju otpada, nalaže se praćenje meteoroloških parametara u toku njene eksploatacije. U aktivnoj fazi eksploatacije deponije merenja: količine padavina, temperature, brzina i smer vazdušnih strujanja, isparavanje i atmo-sferska vlažnost se prate na dnevnom nivou. Merenja se obrađuju u deponijskoj labora-toriji ili se preuzimaju od najbliže meteoro-loške stanice dokle god to zahteva nadležni organ u skladu sa zakonom i uredbom.

\section{Monitoring površinskih voda}

Monitoring površinskih voda vrši se u toku:

- U procesu eksploatacije deponije u cilju upoređivanja sa "nultim stanjem", $i$ to $u$ početku eksploatacije deponije (prvih godinu dana) - na svakih mesec dana, a kasnije na svaka tri meseca. Uzorkovanje vrše akreditovane laboratorije.

- Stalni monitoring površinskih voda u toku eksploatacije deponije sa skraćenim hemijskim i bakteriološkim analizama vrši se na svakih 15 dana u deponijskoj laboratoriji, po osnovu 
Direktive o odlaganju otpada na deponije (1999/33/EC). Sadržaj ispitivanih elemenata $\mathrm{u}$ vodi, kao potencijalni mogući zagađivači površinskih voda, definisan je Uredbom o klasifikaciji voda i kategorizaciji vodotoka (Sl. glasnik RS, broj: 42/01). Parametri koje treba pratiti su: $\mathrm{pH}$ vrednost, temperatura, sedimentne i suspendovane materije, organski parametri $\left(\mathrm{KMnO}_{4}, \mathrm{BPK} 5, \mathrm{HPK}\right)$, nitrati, nitriti, amonijum jon, hloridi, sulfati, sulfidi, cijanidi, deterdženti, ulja i masti, Fe, $\mathrm{Cr}, \mathrm{Cu}, \mathrm{Ni}, \mathrm{Cd}, \mathrm{Zn}, \mathrm{Pb}$ i dr., po proceni ovlašćene laboratorije.

\section{Monitoring procednih voda}

Merenje količine i sastava tj. kvalitativnih i kvantitativnih parametara sakupljene procedne vode, vršiće se na mestu predviđenom za to, jednom mesečno $u$ toku eksploatacije deponije, u skladu sa već navedenom Direktivom. Sastav procedne vode proveravati na parametre koji važe i za površinske vode, a koji su usklađeni sa zakonskim regulativama iz oblasti voda, 4 puta godišnje (kvartalno).

\section{Monitoring podzemnih voda}

Uzorci podzemnih voda se uzimaju iz hidrogeoloških objekata (pijezometara, baterija pijezometara ili osmatračkih bunara) iz najmanje tri tačke, a takvog rasporeda da prate kretanje podzemnih voda. Ova ispitivanja uzoraka podzemnih voda se vrše u cilju eventualnog utvrđivanja dešavanja akcidentnih situacija u zaštitnim slojevima deponije, odnosno utvrđivanja zagađenja podzemnih voda. Pored određivanja sastava podzemne vode vrši se i permanentno merenje nivoa podzemnih voda u ugrađenim pijezometrima oko deponije.

U prvih šest meseci rada deponije na svakih 15 dana vrši se merenje $i$ ispitivanje (skraćene hemijske i bakteriološke analize) podzemnih voda. Uzorci podzemnih voda, koji se uzimaju u vremenskim intervalima, rade se kao kompletne hemijske i bakteriološke analize u akreditovanim ustanovama za tu vrstu ispitivanja, 4 puta godišnje skladu sa zakonom kojim se uredjuju vode, odnosno Uredbom o klasifikaciji voda i kategorizaciji vodotoka (Sl. glasnik RS, broj: 42/01).

\section{Monitoring količine padavinskih voda}

Merenje količine padavinskih voda na prostoru deponije, njenih pratećih objekata i u široj zoni zaštite, vrši se u skladu sa zakonom kojim se uređuju vode.

\section{Monitoring stabilnosti tela deponije}

Monitoring stabilnosti tela deponije, vrši se kroz praćenje podataka o telu deponije i senzorskim praćenjem zaptivne obloge - folije.

\section{Monitoring kvaliteta vazduha u okolini deponije pepela $i$ šljake}

Deponija pepela i šljake kaseta III, u toku redovne eksploatacije, neće predstavljati sekundarni izvor emisije i imisije finih čestica pepela. Ovaj uticaj je umanjen, može se reći u potpunosti eliminisan, jer je transport tehnogene sirovine u okvašenom odnosno u potopljenom stanju, čime se minimizira negativan uticaj odložene hidromešavine na vazduh i tlo u bližoj okolini. S tim u vezi, na predmetnom kompleksu potrebno je povremeno a u skladu sa Zakonom o zaštiti vazduha (Sl. gl. RS, br. 124/11) i Uredbom o vrijednostima kvaliteta vazduha (SL. gl. RS 124/12), praćenje kvaliteta vazduha, Prilog I, IV, navedene Uredbe. Ocenjivanje kvaliteta vazduha, po osnovu člana 8, Zakona o zaštiti vazduha, vrši se obavezno u pogledu koncentracija emisije sumpor-dioksida, azot-dioksida i oksida azota, suspendovanih čestica (PM10, PM2,5), olova, benzena i ugljen-monoksida, ugljovodonici, prizemnog ozona, arsena, 
kadmijuma, nikla i benzo(a)pirena i imisije suspendovanih čestica (PM10, PM2,5), a može i za druge zagađujuće materije, koje su kao takve utvrđene relevantnim međunarodnim propisima. Potrebno je i praćenje parametara vetra (brzina i smer vetra), Hidrometeorološki parametri: temeratura, vlažnost i atmosferski pritisak.

Za praćenje kvaliteta vazduha na nivou Republike Srpske, uspostavljena je republička mreža mernih stanica.

\section{Monitoring otpada (pepela $i$ šljake)}

Monitoring otpada podrazumeva redovno vršenje karakterizacije otpada od strane ovlašćene institucije u skladu sa Zakonom o upravljanju otpadom (Sl. gl. RS 53/02) i Zakonom o izmjenama i dopunama zakona o upravljanju otpadom (Sl. gl. 65/08). Obaveza je Nosioca projekta da o izvršenom monitoringu otpada izveštava Ministarstvo Republike Srpske.

\section{Monitoring kvaliteta zemljišta}

Prema Pravilniku o utvrđivanju dozvoljenih količina štetnih i opasnih tvari $u$ zemljištu i. metode njihovog ispitivanja (Sl. Novine B i H 72/09), član 10, obavezna je redovna kontrola zemljišta, najmanje svake četvrte godine, u blizini većih gradskih naselja, industrijskih objekata i prometnica, zatim zemljišta gdje se odlažu razni otpadni materijali, deponije pepela iz termoelektrana, deponije jalovine.

Navedenim Pravilnikom propisane su granične vrednosti parametara, član 5, 6 i 7 koji se ispituju pri određivanju kvaliteta podzemnih voda, odnosno njihov štetan uticaj na fizička, hemijska i biološka svojstva zemljišta.

\section{Tehničko osmatranje deponije pepela $i$ šljaka}

Tokom dugogodišnjeg perioda eksploatacije deponije, vrši se nadzor nad deponijom pepela i šljake, od strane stručnogovlašćenog lica zaduženog za osmatranje osnovnih parametara, koji su od uticaja na rad deponije, definisanih planom i programom rada deponije. Uvid u osmatrane parametre imaju nadležni i inspekcijski organi, u vidu periodičnih izveštaja. Vođenjem evidencije o stanju na terenu, evidentirano kroz osmatračke dnevnike, neprekidno se prate uticajni parametrie na rad deponije koji mogu izazvati akcidentne situacije sa štetnim uticajem na životnu sredinu, delovanjem različitih spoljašnjih i unutrašnjih faktora na iste i nepridržavanja osnovnih mera zaštite pri radu deponije.

\section{ZAKLJUČAK}

Pravilnim pristupom $\mathrm{u}$ toku izgradnje deponije pepela i šljake, minimizira se njen štetan uticaj na osnovne činioce životne sredine, vodu, vazduh i zemljište.

Praćenjem kvaliteta voda, vazduha i zemljišta, odnosno adekvatnih pokazatelja (elemenata), propisanih zakonskim regulativama i pravilnicima iz predmetne oblasti, ima se jasan uvid u stanje deponije, prvenstveno na stanje podzemnih i površinskih voda, kako ne bi došlo do njihovog ugrožavanja, tj. zagađivanja pepelom usled eventualnog prodora procednih voda $\mathrm{u}$ deponiju, kroz drenažni sistem.

Do akcidentne situacije, zagađivanja podzemnih voda, može doći usled kvara na drenažnom sistemu, a što se može uočiti na vreme i sprečiti eventualni akcident većih razmera, praćenjem stanja u ugrađenim pijezometrima oko deponije, prema izrađenom planu i programu za praćenje stanja, čime se stalno ima uvid u nivo i kvalitet podzemnih voda $\mathrm{i}$ na taj način rizik od zagađenja podzemnih voda svodi na minimum. Preko parametara praćenja kvaliteta podzemnih voda prati se i kvalitet zemljišta.

Praćenje kvaliteta vazduha se vrši po nalogu nadležnog organa, ali uvođenjem nove tehnologije deponovanja kako je već navedeno $u$ radu sa većim sadržajem vode $u$ odnosu na sadržaj pepela u formiranoj hidromešavini, neće doći do razvejavanja pepela, čime se uticaj pepela na vazduh $u$ potpunosti umanjuje. 


\section{LITERATURA}

[1] I. Jovanović, M. Bugarin, S. Magdalinović: Pregled savremenih svetskih istraživanja o karakteristikama letećeg pepela kao sekundarne mineralne sirovine; Deo 1, Mining and Metallurgy Engineering Bor 2/2013, str. 157-166.

[2] M. Mikić, D. Kržanović, M. Ljubojev: Overview of zone monitoring of current collector of the Krivelj River below flotation tailing dump "Veliki Krivelj", Serbia. XV Balkan mineral procesing congress, Proceedings, 12$16^{\text {th }}$ June 2013, Sozopol, Bulgaria.

[3] Lj. Obradović, D. Urošević, G. Tomić: Fizička karakterizacija pepela i šljake sa deponije u Medoševcu, Rudarski radovi 1/2010, str. 57-68.

[4] Tehnički projekat rekultivacije deponije pepela i šljake, Jun 2013.

[5] M. Ljubojev, D. Ignjatović, L. Djurdjevac Ignjatović, V. Ljubojev, Preparations for Investigation the Tunnel Route and Field Surveying, Mining Engineering Journal, No. 1, 2011, str. 135-166.

[6] S. Krstić, M. Ljubojev, M. Mikić, V. Ljubojev: Methods of geotechnical investigations for rehabilitation and remediation the flotation tailing dump Veliki Krivelj (Serbia), XIV Balkan mineral processing congress, proceedings, Jun, 2011, Tuzla, BIH, str. 851853.

[7] S. Krstić, M. Mikić, M. Ljubojev, O. Musić, V. Ljubojev: Conditions of drainage of flotaion tailing of Veliki Krivelj, $43^{\text {rd }}$ International october conference on mining and metallurgy, proceedings, Octobar 2011, Kladovo, Srbija, str. 221-238

[8] M. Mikić, D. Kržanović, S. Krstić: Overview of the current situation of major facilities of the flotation tailing dump Veliki Krivelj near Bor with special review to the collector of the Krivelj River, $43^{\text {rd }}$ International october conference on mining and metallurgy, Proceedings, Octobar 2011, Kladovo, Srbija, str. 303-306.

[9] D. Kržanović, M. Mikić, M. Ljubojev: Analiza prostornog položaja rudničkih objekata rudnika Veliki Krivelj u odnosu na predloženu trasu tunela za izmeštanje Kriveljske reke, Rudarski radovi, 3/2011, str. 89-94

[10] D. Kržanović, M. Mikić, M. Ljubojev: Analiza uticaja razvoja rudnika Veliki Krivelj na izgradnju novih objekata za devijaciju Kriveljske reke, Rudarski radovi 4/2011, str. 49-56.

[11] S. Krstić, R. Lekovski, M. Mikić: Environmental protection from dust from flotation tailings Veliki Krivelj, Air protection 2011, proceedings, Zrenjanin, Hotel Vojvodina 7. - 9. 11. 2011., str. 200-206.

[12] M. Mikić, D. Kržanović, M. Ljubojev. Auscultation and zone monitoring of current collector of the Krivelj river below flotation tailing dump "Veliki Krivelj", Serbia. 12 ${ }^{\text {th }}$ Scientific Geoconference SGEM 2012, proceedings volume I, Geology Exploration and Mining. Proceedings, 17-23 ${ }^{\text {th }}$ June, Albena Bulgaria, str. 465-472.

[13] V. Čudić, D. Kisić, D. Stojiljković, A. Jovović: Ash from thermal power plants assecondary raw material. Institute of Public Health, Belgrade, Economic Society TENT, Obrenovac, University of Belgrade, Faculty of Mechanical Engineering, Belgrade, Serbia, Thermal power plant ash as secondary raw material. april 2007.

[14] List EPCG-Nikšić, januar 2007, http://www.ekopv1.00freehost.com/ elektro.htm

[15] www.ctsafeashlandfill.com

[16] http://www.worldcoal.com/news/ power/articles/Management_of_coal_c ombustion_wastes9

[17] http://www.coalashfacts.org 